\title{
THE BODY DRAMATURGY IN THE ACTOR'S COMPOSITION WORK - THE BODY THAT OPERATES ON IMAGES AND GENERATES AFFECTS
}

\author{
Guilherme Martins Moreira*, Melina Scialom.
}

\begin{abstract}
Could the actor/performer be the dramaturge of his own work, basing his composition through what affects him? This theoretical-practical research sought to investigate the actor's dramaturgy through body's perspective and its capacity to affect and be affected, exploring the creative processes that permeate the scene. For such, this study was articulated in four main axes: laboratories under the methodology "practice as research" (SCIALOM, 2017) ${ }^{1}$; creation, composition and presentation of dramaturgies; compilation and study of authors who dialogue with the theme; and the analysis of the process, relating theory and practice. By means of Choreological and compositional exercises and theoretical readings based on the study of actor's dramaturgy, principles of the movement, body-image and affects, the research systematized practices that sought to increase the self-knowledge and autonomy of the scenic body and challenge the way of think and doing dramaturgy.
\end{abstract}

\section{Key words:}

Actor's dramaturgy; Choreology; Practice as research.

\section{Introduction}

This research starts from the theater director Eugenio Barba's $^{2}$ definition of dramaturgy as the text of representation within a texture of actions, and body dramaturgy as a set of choices and actions physically performed by the actor, in order to organize his living body material through of the configuration of actions, in the composition of a scenic work. It is the texts produced by the actor with his body in space, making him a bodysign, a poet of itself (FALKEMBACH, 2005) ${ }^{3}$.

This work, evidencing the body as a locus of knowledge, investigated body dramaturgy by immersing itself in the Choreological Studies derived from the researches of the choreographers Rudolf Von Laban and Valerie PrestonDunlop ${ }^{4}$, along with theories of affect and body-image, in order to explore the body and movement at its most intimate and place as principal material on the creation of dramaturgies.

\section{Results and Discussion}

The research can be divided into three stages, all finalized with a process open to the public with a discussion after the presentation. The laboratories allowed the systematization of practices that made possible the creation of dramaturgical compositions by the perspective of the actor, through empirical processes. The making of a diary and filming was of paramount importance for the analysis of the results.

In the first stage, exercises related to the principles of Choreological studies were carried out together with works on compositions with images and affects, resulting in an open process based on the work "Composition II" by Kandinsky. The second stage worked on large personal generators of affects and matrices of movement, culminating in the creation of the spectacle "Memories". In the third stage, with the questions raised in the previous processes, the individual relations with affects and images were explored under the idea of dramaturgical texture, which resulted in the creation of a solo performance: "The Blanks Over Someone In Suspension", which sought to fill in the blanks left by "Memories", creating their own blanks.

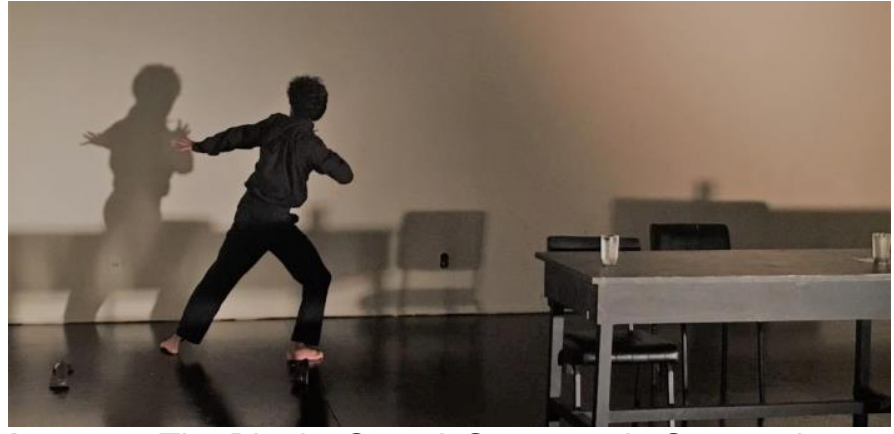

Image 1. The Blanks Over A Someone In Suspension

\section{Conclusions}

It was observed empirically that the body, in its materiality, is susceptible to create images through its physical organization in space-time-environment, as well as to carry images inscribed in it, being a semantic vector of relation with the world, to be read and interpreted in different ways according to the sociocultural contexts involved. In its power and sensibility, this body is susceptible to affect and be affected when in contact with other bodies and environmental factors, in an uninterrupted movement of affects. This research showed that it is possible to use these elements as the main material of creation and composition of a dramaturgy, promoting to the actor great autonomy and strong hearing of itself in the scene.

\section{Acknowledgement}

To PIBIC, CNPq and SAE; to colleagues Melina Scialom, Verônica Fabrini, Ana Felice and Caroline de Lima.

${ }^{1}$ SCIALOM, M. Laban Plural: Arte do Movimento, Pesquisa e Genealogia da Práxis de Rudolf Laban no Brasil. São Paulo, Brasil: Summus, 2017.

${ }^{2}$ BARBA, E. On Directing and Dramaturgy, Burning the House. Oxon: Routledge, 2009; 218 pp.

${ }^{3}$ FALKEMBACH, Maria. Dramaturgia do corpo e reinvenção de linguagem: transcriação de retratos literários de Gertrude Stein na Composição do Corpo Cênico. Florianópolis: Universidade do Estado de Santa Catarina, 2005.

Dissertação (Mestrado em Teatro).

${ }^{4}$ PRESTON-DUNLOP, V.; SANCHEZ-COLBER, A. Dance and the performative: a choreological perspective: Laban and beyond. Alton, Hampshire: Dance books, 2010. 